\title{
Competitive advantages of SMEs: The roles of innovation capability, entrepreneurial orientation, and social capital
}

\author{
Ventajas competitivas de las PYME: el papel de la capacidad \\ de innovación, orientación empresarial, y capital social
}

\author{
Heru Sulistyo*, Sri Ayuni \\ Universitas Islam Sultan Agung, Indonesia
}

Received April 1, 2018; accepted June 27, 2019

Available online August 12, 2019

\begin{abstract}
The purpose of this study is to examine the influence of entrepreneurial orientation and social capital on innovation and performance capabilities in achieving the competitive advantage of small and medium enterprises (SMEs). SMEs contribute significantly to the Indonesian economy, especially in the era of a monetary crisis. Some researches on performance and innovation capabilities in SMEs have focused on finance, operation, and marketing aspects but have not explored the intangible assets such as entrepreneurial and social capital. Intangible assets become a key success factor in improving the performance of SMEs, especially in the era of ASEAN Economic Community 2016. The method used in this research is descriptive and explanatory. The sample of this study is owners of SMEs handicraft in Semarang, Jepara, Kudus, with as many as 254 respondents. Sampling is conducted on SMEs that have been operating for at least five years, having employees over 10 people and still exist up to now. Data were collected by using survey method through closed and open questionnaires and interview. Data analysis was done by using the structural equation model with AMOS program. The results show that there is a significant influence between entrepreneurial orientation and social capital on innovation and performance capabilities. Innovation capability has a significant influence on performance improvement and competitive advantage of SMEs.
\end{abstract}

Keywords: Entrepreneurial orientation; Social capital; Performance; Innovation capability; Competitive advantage

\footnotetext{
*Corresponding author.

E-mail address: heru@unissula.ac.id (H. Sulistyo).

Peer Review under the responsibility of Universidad Nacional Autónoma de México.

http://dx.doi.org/10.22201/fca.24488410e.2020.1983

0186-1042/C2019 Universidad Nacional Autónoma de México, Facultad de Contaduría y Administración. This is an open access article under the CC BY-NC-SA (https://creativecommons.org/licenses/by-nc-sa/4.0/)
} 


\section{Resumen}

Este estudio se propone examinar la influencia de la orientación empresarial y del capital social en las capacidades de innovación y desempeño para lograr la ventaja competitiva de las pequeñas y medianas empresas (pyme).Las pyme contribuyen en forma importante a la economía de Indonesia, especialmente en la era de una crisis monetaria. Algunas investigaciones sobre las capacidades de desempeño e innovación en las pyme se han centrado en aspectos de finanzas, operación, y marketing, pero no han explorado los activos intangibles como capital empresarial y social. Los activos intangibles se vuelven un factor clave de éxito para mejorar el desempeño de las pyme, especialmente en la era de la Comunidad Económica ASEAN (Asociación de Naciones del Sudeste Asiático) 2016. El método utilizado en esta investigación es descriptivo y explicativo. La muestra de este estudio son dueños de pyme artesanales en Semarang, Jepara, Kudus, con una suma de 254 encuestados El muestreo se realiza en pyme que han estado operando durante al menos cinco años, con más de 10 empleados y que todavía existen a la fecha. Se recolectó la información con el uso del método de encuesta y cuestionarios abiertos y entrevistas. Se realizó el análisis de datos mediante el modelo de ecuaciones estructurales con el programa AMOS (Analysis of moment structures). Los resultados muestran que hay una importante influencia entre orientación empresarial y capital social sobre las capacidades de innovación y desempeño. La capacidad de innovación tiene una significativa influencia sobre la mejora del desempeño y la ventaja competitiva de las pyme.

Palabras clave: Orientación empresarial; Capital social; Desempeño; Capacidad de innovación; Ventaja competitiva

\section{Introduction}

Products from Small and Medium Enterprises (SMEs) are facing a very tough competition with the products from other ASEAN countries (ASEAN Economic Community). Innovation capability plays an important role in improving the performance and competitive advantages of products, operations, marketing, human resources and networking in national and international markets. The average of non-oil and gas exports of SMEs in Indonesia amounts to 17.31 percent with an average growth of 8.41 percent per year. The largest export value of SMEs in Indonesia is still dominated by the garment sector. The export contribution of SMEs products increased from $17 \%$ to $18 \%$ in 2013 . The strategic role of SMEs is also shown by the opportunity of creating new entrepreneurs who are currently still relatively low by 0.18 percent which helps overcome the level of open unemployment in Indonesia, with the figure reaching 8.59 million people. From the 110 million workforces in the country, 97.16 percent who work on the sector of SMEs. Thus, the continuous development of SMEs in creating competitive advantage is very important to be done by various stakeholders, especially in 
solving the different problems faced by SMEs in Indonesia, such as human resources, innovation, entrepreneurship and business management.

Innovation becomes the key to success for organizations to increase sales and organizational excellence through new product development (Sulistyo \& Siyamtinah, 2016). Several studies have examined various factors that influence the innovation capability of the organization which are entrepreneurship, marketing capability, relational capital (Sulistyo \& Siyamtinah, 2016); knowledge sharing (Lin, 2007); psychological empowerment (Ertürk, 2012); relationship management (Panayides, 2006); intellectual capital (Wu \& Sivalogathasan, 2013); innovation network (Sáenz \& Bouvier, 2011); organizational knowledge assets (Delgado-verde, Mart1, \& Navas-lo, 2011); customer relationship management (Lin, Chen, \& Chiu, 2010); organizational culture and empowerment (Cakar \& Ertürk, 2010); and informal social interaction (Liu, Huang, Dou, \& Zhao, 2015). All the factors studied showed a significant influence on the improvement of innovation capability. On the other hand, the characteristics of SMEs in Indonesia still face various obstacles of innovation development, especially in terms of entrepreneurship and social capital.

An entrepreneur is a person who innovates, finances and having business intelligence in an effort to transform innovation into economic goods (Yu \& Si, 2012). Entrepreneurs are those who have the courage to take risks and have the motivation and proactive action to create innovations that produce new products, new services or new processes in creating competitive advantage (Wingwon, 2012). The ability and entrepreneurial orientation of SMEs are one of the factors that determine the innovation capability and performance. International entrepreneurship can increase organizational innovation intensity and marketplace performance (O'Cass \& Weerawardena, 2009). Social capital is very important in influencing the innovation capability and company performance (Wu \& Sivalogathasan, 2013).

Innovation involves the process of applying new knowledge. Social networks and interaction activities only explain possibilities and opportunities for innovation, such as knowledge sharing (Lawson et al., 2009). Social networking provides only the basic elements for achieving benefits in relationships, such as knowledge. Knowledge acquisition can be the result of informal social mechanisms, but knowledge acquisition is only one process involved in innovation. (Liu et al., 2015). This study focuses on soft skill aspects of SMEs' actors and the ability to use social capital to encourage innovation and improve performance. Previous studies focused more on the resource-based view from the intangible asset aspects. This study aims to test the entrepreneurial orientation and social capital on innovation capability, performance, and competitive advantage. 


\section{Entrepreneurial Orientation}

The concept of entrepreneurial orientation has been expanded by Covin and Slevin (1988) as a human factor in gaining an international advantage. Entrepreneurial orientation is mostly associated with the ideas of new jobs that can cause some changes in market. The entrepreneurial orientation is an approach that focuses on product market innovation and project risks and has a tendency to be a pioneer in innovation and excellence over competitors (Miller, 1983). The entrepreneurial orientation approach improves the company's ability and provides technical knowledge, which is an enabling approach to introduce technical solutions to address consumer needs (Gatignon and Xuereb, 1997; Workman, 1993). A number of studies in the field of entrepreneurial orientation have shown linkage with other variables such as company performance (Matsuno, Mentzer and Özsomer, 2002). Entrepreneurial scholars have sought to use intangible resources to improve the company's performance, particularly with regards to entrepreneurial orientation (EO) (Wiklund and Shepherd, 2003). Especially in the service industry, small and medium enterprises (SMEs) are increasingly under pressure from global competition and other countries. With the importance of entrepreneurial orientation, researchers have examined the impact of social capital from entrepreneurial orientation and performance of companies. Research by Maatoofi \& Tajeddini (2011) concludes that product quality, marketing synergy, and expertise in new product offerings have no significant effect between entrepreneurial orientation and market orientation of companies. The results also show that the manager's support for innovation is more dominant in entrepreneurial orientation than marketing orientation. The study conducted by Lee \& Chia (2010) concluded that entrepreneurial orientation has a significant effect on innovation capability.

\section{Social Capital}

Social capital is not an entity, but it is different entities that have two common characteristics. Social capital consists of several aspects of social structure and facilitates the actions of individuals within the structure. Collective action and value creation for companies can be achieved if the organization's social capital is realized through shared goals among employees (Leana and Van Buren, 1999; Tsai and Ghosal, 1998). Nahapiet and Ghosal (1998) divide the social capital of organizations into three dimensions, which are structural, relational and cognitive. Structural dimension is non-personal relationships among individuals or units within the organization, showing patterns of relationships and interactions among people in the organization to learn, share and exchange information, ideas and knowledge. Relational dimension is an interpersonal relationship between individuals in organizations that focus on special relationships such as respect and friendship that affect employees' behavior and 
also show trust among employees, helping each other between employees when needed, and honesty, share feelings and respect to each other. The cognitive dimension shows sources that provide shared interpretation and concepts between individuals in the same social network. This shows how much employees have a clear understanding and perception of the organization's values and goals and how much they accept and commit to the organization goals. According to Putnam (2000), social capital has two types, namely internal and external social capital. Internal social capital is a process of internalizing activities within the organization that is built internally within the organization itself through various resources owned by the company in the form of human resources and organizations that grow in a social complexity of the company and social capacity. External social capital is built through the company's ability to develop its various social networks and environments, networking outside the organization, building trust, adherence to norms, and social cohesion with society. Research conducted by Lee and Hsich (2010) concluded that entrepreneurial has a significant influence on innovation capability. Sanchez et al. (2014) discovered that internal social capital is significantly related to innovation. In addition, Yi Ching (2006) concluded that social capital has a significant effect on innovation.

\section{Innovation Capability}

Innovation is a new idea, practice, and object from individuals (Fruhling \& Siau, 2007). Innovation capability is the implementation and creation of technology applied to new systems, policies, programs, products, processes and services to the organization (Liao et al., 2009). It is also defined as the ability to absorb and use external information to be transferred into new knowledge (Cohen and Levinthal, 1990). Innovation capability is a comprehensive set of organization characteristics that facilitates and drives innovation strategies (Wu \& Sivalogathasan, 2013). Weerawardena (2003) defined innovation as a modification of products, processes, services, organizational systems, and marketing systems to create customer value. Innovation capability consists of technical innovation and administrative innovation (Damanpour, 1991). According to Lin et.al, (2009), innovation capability consists of product innovation, process innovation, marketing innovation, service innovation, and administrative innovation. Research conducted by Wu \& Sivalogathasan (2013) concluded that high innovation capabilities within the organization will improve the company's performance. Innovation is an important organizational capability because the success of new products is a growth engine and has an impact on increasing sales, profits, and competitive power for many organizations (Pauwels et al., 2000). Some research findings agree that there is a direct and positive relationship between innovation and superior performance (Hult et al. 2004; Panayides, 2006; Thornhill, 2006). Hult et al. (2004) describe innovation as a new process, product and organizational idea. In- 
novation is defined as a process that begins with ideas, results of discovery and introductory results of new products, processes and services on the market (Thornhill, 2006). The impact of innovation on performance has been intensively tested in recent research and the results show a significant effect. Research conducted by Lee and Hsich (2010) concluded that the innovation capability directly affects the company's competitive advantage. Dorson (2018) found that innovation had significant effect on the competitive advantage. While Higon (2011) found that the age of the company had a significant impact on the effects of innovation on competitive advantage.

H1: Entrepreneurial orientation has a significant effect on innovation capability

H2: Social capital has a significant effect on innovation capability

H3: Entrepreneurial orientation has a significant effect on performance

H4: Social capital has a significant effect on performance

H5: Innovation capability has a significant effect on performance

H6: Innovation capability has a significant effect on competitive advantage

H7: Performance has a significant effect on competitive advantage

\section{Methodology}

\section{Sample and Data Collection}

The sample in this research is the actors of SMEs in the creative and handmade fashion industry in Central Java, Indonesia as many as 300 people, but questionnaires that were filled and returned only 254 people (response rate 84,67\%). The sampling used was purposive sampling method based on the consideration of SMEs in creative and handmade industries that have been operating for at least 10 years, having employees at least 20 people and its business still exist up to now. Old SMEs operating tend to produce a lot of product innovation well. Before the questionnaires were given to the respondents, trials on 20 SME owners conducted by surveyors to determine the level of understanding among respondents regarding the questions given. The results show that the respondent understands the questions posed well and has a good consistency of answers. Data collection is done by asking several questions to the SMEs owners by using the questionnaire instrument. The questionnaire consists of closed questions, where the respondent only needs to provide a cross on a scale of 1 to 7 . In addition 


\section{Table 1}

Mean value, deviation standard, standard loading, construct reliability and index

\begin{tabular}{|c|c|c|c|c|c|c|}
\hline indicators & mean & deviation standard & std loading & $\begin{array}{l}\text { construct } \\
\text { reliability }\end{array}$ & index & category \\
\hline $\begin{array}{l}\text { entrepreneurial } \\
\text { orientation (eo) }\end{array}$ & & & & 0,847 & & \\
\hline eo1 & 5,29 & 0,958 & 0,786 & & 75,534 & high \\
\hline eo2 & 5,17 & 0,968 & 0,787 & & 73,791 & high \\
\hline eo3 & 5,13 & 0,944 & 0,731 & & 73,341 & high \\
\hline eo4 & 5,30 & 0,989 & 0,744 & & 75,703 & high \\
\hline $\begin{array}{l}\text { social capital } \\
(\mathrm{sc})\end{array}$ & & & & 0,858 & & \\
\hline $\mathrm{sc} 1$ & 5,11 & 1,023 & 0,802 & & 73,003 & high \\
\hline $\mathrm{sc} 2$ & 5,28 & 1,053 & 0,834 & & 75,366 & high \\
\hline sc3 & 5,20 & 0,920 & 0,718 & & 74,241 & high \\
\hline $\operatorname{sc} 4$ & 5,32 & 1,035 & 0,745 & & 75,984 & high \\
\hline $\begin{array}{l}\text { innovation } \\
\text { capability (ic) }\end{array}$ & & & & 0,865 & & \\
\hline ic1 & 5,19 & 1,047 & 0,813 & & 74,184 & high \\
\hline ic2 & 5,02 & 0,949 & 0,765 & & 71,654 & high \\
\hline ic3 & 5,19 & 1,014 & 0,725 & & 74,072 & high \\
\hline ic4 & 5,20 & 1,042 & 0,788 & & 74,297 & high \\
\hline ic5 & 5,24 & 0,959 & 0,652 & & 73,552 & high \\
\hline performance (p) & & & & 0,846 & & \\
\hline p1 & 5,37 & 0,997 & 0,781 & & 76,772 & high \\
\hline $\mathrm{p} 2$ & 5,38 & 1,001 & 0,773 & & 76,828 & high \\
\hline p3 & 5,27 & 1,021 & 0,723 & & 75,253 & high \\
\hline $\mathrm{p} 4$ & 5,25 & 1,017 & 0,764 & & 75,028 & high \\
\hline $\begin{array}{l}\text { competitive } \\
\text { advantage (ca) }\end{array}$ & & & & 0,868 & & \\
\hline $\mathrm{cal}$ & 5,52 & 1,013 & 0,803 & & 78,796 & high \\
\hline $\mathrm{ca} 2$ & 5,38 & 1,063 & 0,840 & & 76,884 & high \\
\hline $\mathrm{ca} 3$ & 4,80 & 1,018 & 0,657 & & 68,616 & moderate \\
\hline $\mathrm{ca} 4$ & 5,46 & 0,984 & 0,847 & & 78,065 & high \\
\hline
\end{tabular}


Table 2

Comparison of Correlation Coefficients With AVE Squares

\begin{tabular}{lcccc}
\hline relationship & $\begin{array}{c}\text { correlation } \\
\text { coefficient }\end{array}$ & \multicolumn{2}{c}{$\begin{array}{l}\text { cut of } \\
\text { value }\end{array}$} & description \\
\hline eo $\rightarrow$ p & 0,30 & 0.872 & & valid \\
eo $\rightarrow$ ic & 0,40 & & & valid \\
$\mathrm{sc} \rightarrow$ ic & 0,32 & 0,881 & valid \\
$\mathrm{sc} \rightarrow \mathrm{p}$ & 0,28 & & correlation $_{\text {ave }^{2}}$ & valid \\
$\mathrm{ic} \rightarrow \mathrm{p}$ & 0,43 & 0,867 & & valid \\
$\mathrm{ic} \rightarrow \mathrm{ca}$ & 0,43 & & & valid \\
$\mathrm{p} \rightarrow \mathrm{ca}$ & 0,43 & 0,872 & & valid \\
$\mathrm{ca}$ & & 0,889 & & \\
\hline
\end{tabular}

to closed questions, the respondent must also answer open questions, both the profile of the respondent and related to each research variable. Interviews were conducted by surveyors to each respondent after filling out the questionnaire. The interview was conducted for 30 minutes to explore more about the condition of SMEs in terms of entrepreneurial orientation, social capital and innovation and performance of SMEs.

The completed questionnaires were then distributed to respondents with the help of surveyors and group business leaders together with each creative handmade and fashion industries for 2 months. The results of collecting questionnaires were verified and edited for the purpose of data processing.

\section{Measurement}

The entrepreneurial orientation is measured by indicators of innovation ability, proactivity, and risk-taking courage. Social capital is measured by cognitive capital, structural capital and relational capital. Innovation capability consists of product innovation, process innovation, innovation administration, innovation marketing, and service innovation. Competitive advantages consist of low cost, quality of products or services, $\mathrm{R} \& \mathrm{D}$, and innovation. Everything is measured by using Likert scale 1 to 7,1 for strongly disagree and 7 for strongly agree.

\section{Results}

Index number analysis is used to describe the respondent's perception of the question posed. The resulting index starts from numbers 1 to 7 , so that the lowest index number is produced at $14.29 \%$ to $100 \%$. This analysis used the three-box method to get range $28,57 \%$. 
Table 3

Assessment of Normality

\begin{tabular}{|c|c|c|c|c|c|c|}
\hline Variable & $\min$ & $\max$ & skew & c.r. & kurtosis & c.r. \\
\hline CA1 & 3,000 & 7,000 &,- 226 & $-1,470$ &,- 535 & $-1,740$ \\
\hline CA4 & 3,000 & 7,000 &,- 188 & $-1,220$ &,- 538 & $-1,751$ \\
\hline CA3 & 3,000 & 7,000 & ,085 &, 556 &,- 647 & $-2,106$ \\
\hline CA2 & 3,000 & 7,000 &,- 273 & $-1,775$ &,- 646 & $-2,102$ \\
\hline $\mathrm{P} 1$ & 3,000 & 7,000 &,- 226 & $-1,468$ &,- 544 & $-1,770$ \\
\hline P4 & 3,000 & 7,000 &,- 158 & $-1,028$ &,- 587 & $-1,909$ \\
\hline P3 & 3,000 & 7,000 &,- 174 & $-1,131$ &,- 586 & $-1,907$ \\
\hline P2 & 3,000 & 7,000 &,- 147 &,- 959 &,- 617 & $-2,008$ \\
\hline IC1 & 3,000 & 7,000 &,- 164 & $-1,064$ &,- 516 & $-1,679$ \\
\hline $\mathrm{IC} 2$ & 3,000 & 7,000 &,- 226 & $-1,470$ &,- 523 & $-1,700$ \\
\hline IC3 & 3,000 & 7,000 &,- 012 &,- 077 &,- 475 & $-1,546$ \\
\hline IC4 & 3,000 & 7,000 &,- 261 & $-1,698$ &,- 490 & $-1,594$ \\
\hline IC5 & 3,000 & 7,000 &,- 234 & $-1,524$ &,- 307 & $-1,000$ \\
\hline $\mathrm{SC} 1$ & 3,000 & 7,000 &,- 066 &,- 432 &,- 551 & $-1,794$ \\
\hline $\mathrm{SC} 2$ & 3,000 & 7,000 &,- 161 & $-1,045$ &,- 502 & $-1,634$ \\
\hline $\mathrm{SC} 3$ & 3,000 & 7,000 &, 242 & 1,575 &,- 583 & $-1,898$ \\
\hline $\mathrm{SC} 4$ & 3,000 & 7,000 &,- 195 & $-1,269$ &,- 573 & $-1,864$ \\
\hline EO4 & 3,000 & 7,000 &,- 208 & $-1,354$ &,- 541 & $-1,760$ \\
\hline EO3 & 3,000 & 7,000 &,- 269 & $-1,750$ &,- 500 & $-1,626$ \\
\hline $\mathrm{EO} 2$ & 3,000 & 7,000 &,- 283 & $-1,839$ &,- 470 & $-1,529$ \\
\hline EO1 & 3,000 & 7,000 &,- 221 & $-1,440$ &,- 505 & $-1,644$ \\
\hline Multivariate & & & & &,- 005 &,- 001 \\
\hline
\end{tabular}

The index with a range of $14.29 \%-42.86 \%$ was at the low category, $42.87 \%-71.41 \%$ at the moderate category and $71.42 \%-100 \%$ at the high category.

Table 2 shows that the square root value of AVE for all constructs is greater than the correlation value. Thus, it can be convluded that the indicators of all the studied constructs are completely different and have met the criteria of discriminant validity.

\section{Test Assumptions Model of Structural Equations}

Test outlier data with Chi-square value $(\chi 2)$ to distance-squared mahalanobis values at 
Table 4

A summary of conformity index of structural model

\begin{tabular}{lccc}
\hline \multicolumn{1}{c}{ conformity index model } & output amos.22 & cut-off value & description \\
\hline chi-squared $\left(\chi^{2}\right)$ & 207,997 & $<170,81$ & good \\
significance of probability & 0,082 & $>0,05$ & good \\
cmin/df & 1,149 & $\leq 2.0$ & good \\
gfi & 0,928 & $>0,90$ & good \\
agfi & 0,908 & $>0,90$ & good \\
tli & 0,987 & $>0,95$ & good \\
cfi & 0,989 & $>0,95$ & $\leq 0.08$ \\
rmsea & 0,024 & good \\
\hline
\end{tabular}

\section{Parameter Assessment Results from Research Model}

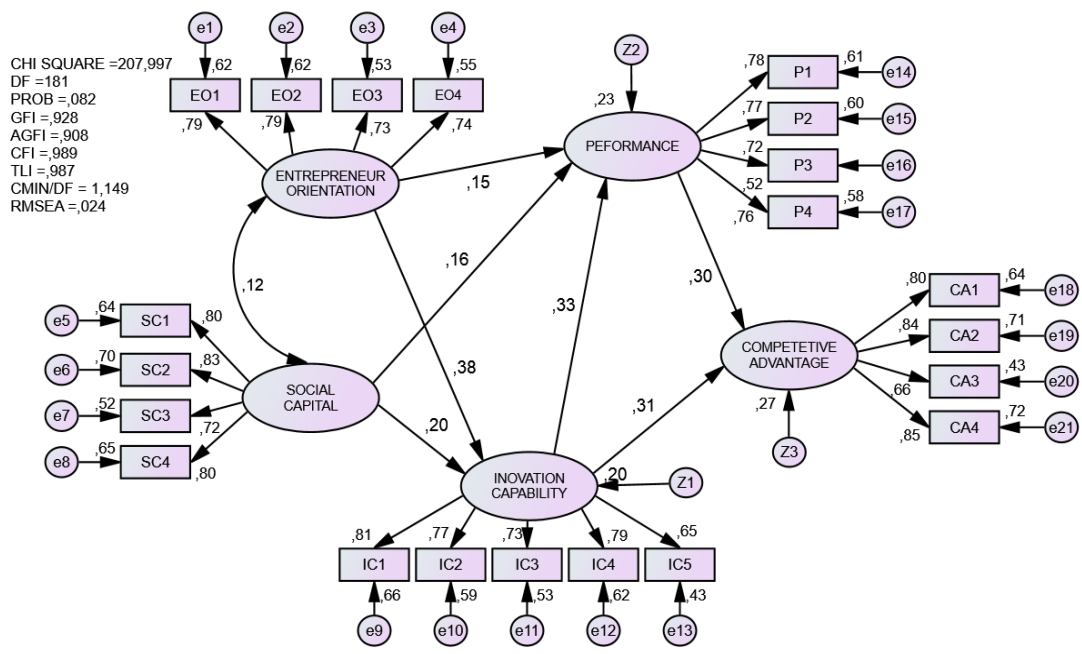

Figure 1. Full Structural Model

$1 \%$ level of degree with degree of freedom number of variables observed in research model. If there are observations that have a distance-squared mahalanobis greater than Chi-squared 
Table 5

Regression of Full Structural Model

\begin{tabular}{|c|c|c|c|c|c|c|c|}
\hline & & & Estimate & $\begin{array}{c}\text { Std } \\
\text { Estimate }\end{array}$ & S.E. & C.R. & $\mathrm{P}$ \\
\hline Innovation Capability & $\leftarrow$ & Social Capital & ,149 & ,198 &, 052 & 2,851 & ,004 \\
\hline Innovation Capability & $\leftarrow$ & $\begin{array}{l}\text { Entrepreneur } \\
\text { Orientation }\end{array}$ &, 317 &, 381 & ,063 & 4,993 & $* * *$ \\
\hline Performance & $\leftarrow$ & Social Capital &, 149 &, 160 &, 065 & 2,293 & ,022 \\
\hline Performance & $\leftarrow$ & $\begin{array}{l}\text { Entrepreneur } \\
\text { Orientation }\end{array}$ &, 159 & ,154 & ,079 & 2,017 & ,044 \\
\hline Performance & $\leftarrow$ & $\begin{array}{l}\text { Innovation } \\
\text { Capability }\end{array}$ & ,406 &, 328 &, 102 & 3,998 & $* * *$ \\
\hline Competitive Advantage & $\leftarrow$ & Performance &, 344 & ,298 & ,088 & 3,895 & $* * *$ \\
\hline Competitive Advantage & $\leftarrow$ & $\begin{array}{l}\text { Innovation } \\
\text { Capability }\end{array}$ &, 445 &, 312 &, 110 & 4,029 & $* * *$ \\
\hline
\end{tabular}

and / or $\mathrm{p} 1$ or $\mathrm{p} 2$ value less than 0.001 , then the observations are excluded from the data tabulation. Based on the results, the observation data have met the requirement, because it has distance-squared mahalanobis value with $\mathrm{p} 2$ value greater than 0.001 . Thus, the data does not contain multivariate outlier symptoms. There is distribution of data to meet the assumption of normality both univariate and multivariate normality. It can be seen from the coefficient c.r skewness and kurtosis that have value lower than $\pm 2.58(\mathrm{Z}=0,05 / 2)$. Detection of symptoms of multicollinearity and singularity can be seen in the determinants of the sample covariance matrix. If the determinant of the sample covariant matrix is equal to zero ( 0 ) then the data is not yet free from multicollinearity. The results of data show that the determinant value of the sample covariance matrix is greater than zero. This means that the data are free from multicollinearity.

Based on the output of data processing with Amos shown in Table 3, it can be concluded that there is a distribution of data fulfilling the assumptions of normality both univariate normality and multivariate normality. This can be seen from the coefficient c.r skewness and kurtosis have value lower than $\pm 2.58(\mathrm{Z}=0,05 / 2)$.

The results of conformity model indicate that all criteria are met so that the model is categorized as good. The value of each index produced from the analysis of this research data is shown in Table 4.

The results of data processing have tested 7 (Nine) hypotheses with AMOS 22.00 as shown in Table 5. 
The results of data analysis by using AMOS program showed that the estimation parameter of Entrepreneur Orientation influence on innovation capability $(\beta 1)$, showed the significant result with standardized estimate value $\beta 1=0,317$, and critical ratio (CR) 4,993 and p-value $=* * *$. These values have met the acceptance requirements of the hypothesis that the value of CR> 1.96 at the level of significance $<0.05(\mathrm{P}=* * *)$. Hypothesis $1(\mathrm{H} 1)$ is supported, the higher the entrepreneurial orientation conducted by SMEs, the higher the innovation capability. The influence of social capital on innovation capability shows a significant result with standardized estimate value $\beta 1=0,149$, and critical ratio $(\mathrm{CR})$ equal to 2,851 and $\mathrm{p}$-value $=0,004$. $\mathrm{CR}$ value $>1.96$ at significance level $<0.05$. Hypothesis $2(\mathrm{H} 2)$ is supported and has a significant effect. Entrepreneurial orientation has a significant effect on performance with standardized estimate value $\beta 3=0,159$, and critical ratio (CR) equal to 2,017. and $p$-value $=0,044$. These values have met the acceptance requirements of the hypothesis that the value of $\mathrm{CR}>1.96$ at the level of significance p-value $<0.05$. Hypothesis 3 (H3) is supported and significant. Social capital has significant influence on Performance $(\beta 4)$, with standardized estimate value $\beta 4=$ 0,149 and critical ratio (CR) 2,293 and $p$-value $=0,022$. These values have met the acceptance requirements of the hypothesis that the value of $\mathrm{CR}>1.96$ at the level of significance $\mathrm{p}$-value $<0.05$. Hypothesis 4 (H4) is supported and significant. The effect of innovation capability on Performance $(\beta 5)$ is significant with the value of standardized estimate $\beta 5=0.406$ and critical ratio $(\mathrm{CR})$ of 3.998 and $(\mathrm{P}=* * *)$. $\mathrm{CR}$ value $>1.96$ at $\mathrm{p}$-value significance level $<0.05$. Hence, hypothesis 5 (H5) is supported and significant. Innovation capability have significant effect on competitive advantage with standardized estimate value $\beta 4=0,445$ and critical ratio (CR) 4,209 and $(\mathrm{P}=* * *), \mathrm{CR}$ value $>1.96$ at level significance of $\mathrm{p}$-value $<0.05$. Hypothesis 6 (H6) is supported and significant. Performance has significant effect on competitive advantage with value of standardized estimate $\beta 7=0,344$ and critical ratio $(\mathrm{CR})$ equal to 4,029 and $(\mathrm{P}=* * *)$. Furthermore, hypothesis 7 (H7) is supported and significant.

Testing the role of intervening variables of innovation capability and performance is done by using Sobel test. Innovation capability mediates the influence of entrepreneurial orientation on performance, Sobel statistical value $=2,839$ and probability $=0,004 \leq p$-value 0,05. Innovation capability mediates the effect of social capital on performance, Sobel statistical value $=2,456$, probability value $=0,014 \leq$ p-value 0,05 . Performance mediates the innovation capability on competitive advantage, Sobel statistical value $=2,331$, probability value $=$ $0,019 \leq \mathrm{p}$-value 0,05 . This can be proven from the Sobel test value that all are greater than 1.96 , with p-value below 0.05 .

\section{Discussion}

The entrepreneurial orientation has a significant impact on company performance, especially 
SMEs. This is related to the dynamics of the product cycle of SMEs which produce an uncertain future and reduce profits. Consequently, efforts are needed to encourage current operations to seek new ideas and new opportunities (Rahomee \& Aljanabi,2017). The entrepreneurial orientation of big business people will encourage the enhancement of innovation capability in the organizations both a large, medium and small micro enterprises (SMEs). Companies that often do product innovation and design will increase its innovation capability to produce creativity, new product ideas, new processes, and new marketing methods. New initiatives and breakthrough by business people will result in sustainable innovation. SMEs that are always active in supporting new ideas, novelty, experiments, and creative processes with the support of existing technology will encourage and accelerate the ability of innovation and performance, especially in the handicraft business. New ideas on product design and process on an ongoing basis will be able to attract more consumers and have an impact on increasing sales, profits and competitive advantage of SMEs. But on the contrary, if the SMEs have limited resources, both in terms of knowledge and technology, this will become an obstacle in innovating the organization (Jaakson et al., 2011). The study results support the finding of Maatoofi \& Tajedinni (2011); Lee \& Hsich (2010) stated that the higher the entrepreneurial orientation of the organization through various development of new ideas, actively anticipating various changes in future needs in the market and the courage to take risks, control and evaluate risks and strategic decisions will encourage in increasing organizational innovation capability. Proactive steps were taken by SMEs to deal with uncertain and changing future situations and overcome the competitor's actions. They strive to always develop creative and innovative efforts to anticipate opportunities that exist in a tight competitive environment and outperform competitors' actions, especially in the era of global competition. Companies that actively conduct business development will be confronted with various obstacles and opportunities.Therefore, it will encourage better innovation capability. The willingness of companies and SMEs to join association member will promote better innovation capabilities by sharing informationand ideas in new product development, new marketing, or technology.

For SMEs who have a low entrepreneurial orientation, they will tend to be reactive, reject risk and become more imitators of competitors. It will certainly be difficult to create innovative capabilities in various stages of the process and product design and improve business performance and sustainable competitive advantage. In addition to innovation and proactive factors, the courage to take risks also determines the ability of innovation and performance. Risk taking is another important dimension of entrepreneurial orientation. This becomes a weakness that is often faced by SMEs (Sulistyo \& Ayuni, 2016). Risk taking is related to the willingness of managers to take risky projects and the courage to take action to achieve company goals. Entrepreneurial orientation will be effective if SMEs have the courage to take risks, especially those related to business development. The results of this study also support 
the finding of Covin and Slevin (1986); Hult et al., (2003); Wiklund and Shepherd, (2003), that businesses with a strong entrepreneurial orientation have better performance than companies that do not adopt an entrepreneurial orientation. Rauch et al. (2009) found a positive correlation between entrepreneurial orientation and business performance. However, several studies did not find a significant relationship between entrepreneurial orientation and performance (Covin et al., 1988). The innovation capability mediates the effect of entrepreneurial orientation on performance. Companies and SME's who has the courage to take risks and always active in business development will have higher success and a significant increase in performance, if the ability in innovation is well. This study supports the findings of company performance (Matsuno et al.,2002).

Social capital is a set of resources embedded in relationships that include aspects such as social interaction, social ties, trusting relationships, value systems and facilitating action in certain social contexts (Nahapiet and Ghoshal, 1998; Tsai and Ghoshal, 1998). In the context of SMEs, social capital is one of the important elements in forming social bonds and interactions in an association of institutions, where each SMEs can support each other, especially in terms of sharing knowledge about process of design and products in enhancing the innovation capabilities of SMEs owners. Trusts and norms that are formed encourage behavior that is suitable for sharing knowledge through cognitive skills and communication (Anklam, 2002). Solidarity, self-confidence, and facilitating the running of a business are the results of social relations that involve among SMEs who are able to provide access to valuable resources such as information, influence, and solidarity. Some of the advantages of SMEs are simpler organizational structures that offer flexibility, effective and open communication channels and lower resistance to change (Kim \& Shim, 2018). Through social capital, SMEs gain learning, knowledge, and experience so as to encourage and accelerate the innovation capability. This happens because in an SME association that is carried out informally between them will create strong cohesion and trust, so there is an exchange of creative ideas about processes and products as a manifestation of the desire to improve the performance of each business and striving to gain competitive advantage. The emotional bond of social capital provides additional information in the SMEs so that it can encourage in increasing efficiency arising from reciprocal commitments involving new opportunities at lower costs (Shane and Venkataraman, 2000).

Social capital has a very important role in improving the innovation capabilities and performance. SMEs who have same value with employees and consumers, all policies and priority programs of business development also appropriate with the interests of employees will encourage the spirit and passion to improve innovation capabilities. A well corporate atmosphere, mutually supporting, trusting and exchanging information in making the decision will encourage the formation of product innovation ideas that have an impact on performance 
improvement. The results support the finding of Sanchez et al. (2014) and Yin Ching (2006) that social capital is significantly related to innovation. The capability of innovation mediates the effect of social capital on performance.

Innovation capabilities have a significant effect on performance and competitive advantages. Companies and SME's who are always looking for the new methods of sustainable design and quality will be the first activator to benefit. The success of a new product is a growth encourager and has an impact on the increasing sale, profits, and competitive power for many organizations. Therefore, innovation capabilities include design, product, process, marketing, and service will encourage high performance and sustainable competitive advantages. This study supports the findings of Wu and Sivalogathasan (2013) that high innovation capabilities in organizations will improve company performance. Thus, there is direct and positive relationship between innovation and high performance. This supports the finding of Hult et al. (2004); Hurley and Hult (1998); Keskin (2006); Panayides (2006); Tornhill (2006).

\section{Conclusion}

The study discusses the importance of entrepreneurial orientation and social capital in improving the innovation capability of SMEs in Central Java, Indonesia. The results showed that the ability of innovation of SMEs in producing products can be done if the actors of SMEs have a high entrepreneurial orientation. The entrepreneurial orientation and social capital are very important in promoting innovation capability in organization, especially SMEs. So far, one of the weaknesses of SMEs is the courage to innovate and to take risks. It is very important for SMEs to improve entrepreneurial orientation that includes innovation, proactivity, and risk-taking that are useful for renewing established businesses and increasing competitiveness in the market, especially in the field of handicraft. The tendency to engage and support new ideas, novelty, experiments, and creative processes requires knowledge, skills, technology and support from various stakeholders involved. In the rapidly changing business environment through various innovations and technological developments, SMEs must be able to adapt and anticipate these changes quickly through the creation of sustainable innovations adjusted to market needs. Handicraft owners must have agility in facing market dynamics and respond as soon as possible so that they become always the first movers. Without the ability of rapid innovation, it is very difficult for SMEs to gain business performance and competitive advantage. It needs support from the government, SMEs, university and associations for coaching, training and mentoring activities in a holistic manner, both knowledge of innovation, the ability to analyze the environment and its decisions and strengthening the courage to take risks. Thus, organizations such as SMEs need to improve their entrepreneurial skills through various motivational strengthening, training, and workshops and mentoring 
will have an innovative, creative, risk-taking spirit in decisions. SMEs also need to improve internal consolidation by strengthening the organization's values to all employees in order to have suitability between the organization and the needs and desires of employees. This can be done by enabling the sharing of formal and informal meetings with various parties, either among employees, SMEs, or government. SMEs that are able to innovate on an ongoing basis will result in a significant performance and impact on competitive advantage.

This research focuses on the field of SMEs engaged in the handicraft industry, where the number of samples is still relatively small compared to the total number of SMEs. Hence, its generalization is still relatively limited to SMEs of handicraft. Future research needs to expand the field of SMEs which involves several important factors in driving the creation of innovation for SME managers in achieving competitive advantage.

\section{References}

Anklam, P. (2002), "Knowledge management: the collaboration thread", Bulletin of the American Society for Information Science and Technology, Vol. 28 No. 6, pp. 1-8. https://doi.org/10.1111/j.1540-627x.2010.00297.x.

Cakar, N. D., and Alper Ertürk. Comparing Innovation Capability of Small and Medium-Sized Enterprises: Examining the Effects of Organizational Culture. Vol. 48, no. 3, 2010, pp. 325-59. https://doi.org/10.1111/j.1540627x.2010.00297.x.

Cohen, W. M \& Levinthal, D. A. (1990). Absorptive capacity: a new perspective on learning and innovation. Administrative Science Quarterly. 35(1):128-152.. https://doi.org/10.2307/2393553.

Covin, Jeffrey G. and Slevin, Dennis P. (1988), The influence of organizational structure on the utility of an entrepreneurial top management style, Journal of Management Studies, 23 (3): 217-234. https://doi. org/10.2307/2393553.

Covin, J.G. and Slevin, D.P. (1986), The development and testing of an organizational-level entrepreneurship scale", in Ronstadt, R., Honaday, J.A., Peterson, R. and Vesper, K.H. (Eds), Frontiers of Entrepreneurship Research, pp. 628-639.

Damanpour, F. (1991), Organizational innovation: a meta analysis of effects of determinants and moderators, Academy of Management Journal, Vol. 34 No.3, pp. 555-90. https://doi.org/10.5465/256406.

Darroch, J. (2005). Knowledge management, innovation and firm performance, 9(3), 101-115. https://doi. org/10.1108/13673270510602809.

Dorson, T.A, (2018). Innovation and competitive advantage creation: The role of organisational leadership in service firms from emerging markets, International Marketing Review, Vol. 35 No. 4, 2018 pp. 580-600. https:// doi.org/10.1108/imr-11-2015-0262.Delgado-verde, M., Mart1, G., \& Navas-lo, E. (2011). Organizational knowledge assets and innovation capability, 12(1), 5-19. https://doi.org/10.1108/14691931111097890.

Ertürk, a. (2012). Linking psychological empowerment to innovation capability: investigating the moderating effect of supervisory trust. International Journal of Business and Social Science, 3(14), 153-166. Retrieved from http://ijbssnet.com/journals/Vol_3_No_14_Special_Issue_July_2012/17.pdf.

Fruhling, A. L., \& Siau, K. (2007). Assessing organizational innovation capability and its effect on e-commerce initiatives. Journal of Computer Information Systems, 47(4), 133-145. https://doi.org/10.1080/10919392.201 5.1087702 .

Gatignon, Hubert and Xuereb, Jean-Marc (1997), Strategic orientation of the firm and new product performance, Journal of Marketing Research: 34: 77-90. https://doi.org/10.1177/002224379703400107. 
Higon, D. A.,(2011). The impact of ICT on innovation activities: Evidence for UK SMEs. International Small Business Journal, 30(6), 684-699. https://doi.org/10.1177/0266242610374484.

Hult, G.T.M., Snow, C.C. and Kandemir, D. (2003), "The role of entrepreneurship in building cultural competitiveness in different organizational types", Journal of Management, Vol. 29 No. 3, pp. 401-426. https://doi. org/10.1016/s0149-2063_03_00017-5.

Hult, G. T., Hurley, R., \& Knight, G. (2004). Innovativeness: Its antecedents and impact on business performance. Industrial Marketing Management, 33(5), 429-438. https://doi.org/10.1016/j.indmarman.2003.08.015.

Jaakson, K., Tamm, D. and Ha "mmal, G. (2011), “Organisational innovativeness in Estonian biotechnology organisations", Baltic Journal of Management, Vol. 6 No. 2, pp. 205-26. https://doi.org/10.1108/17465261111131811.

Kim, N., \& Shim, C. (2018). Social capital, knowledge sharing and innovation of small- and medium-sized enterprises in a tourism cluster, International Journal of Contemporary Hospitality Management ,Vol. 30 No. 6 , 2018 pp. 2417-2437. https://doi.org/10.1108/ijchm-07-2016-0392.

Lawson, B., Petersen, K. J., Cousins, P. D., \& Handfield, R. B. (2009). Knowledge Sharing in Interorganizational Product Development Teams: The Effect of Formal and Informal Socialization Mechanisms. Journal of Product Innovation Management, 26(2), 156-172. https://doi.org/10.1111/j.1540-5885.2009.00343.x.

Leana, C.R. and Van Buren, H.J. (1999), "Organizational social capital and employment practices", Academy of Management Review, Vol. 24 No. 3, pp. 538-555. https://doi.org/10.5465/amr.1999.2202136.

Lee Jia Sheng \& Chia Jung Hsich. (2010). A research in relating entrepreneurship, marketing capability, innovative capability and sustained competitive advantage, Journal of Business \& Economic Research, September, 109119. https://doi.org/10.19030/jber.v8i9.763.

Liao, S., Fei, W \& Chen, C. (2009). Knowledge sharing, absorptive capacity and innovation capability: an empirical study of Taiwan's knowledge-intensive industries. Journal of Information Science. 33 (3): 160-167. https:// doi.org/10.1177/0165551506070739.

Lin, H.-F. H.-F. (2007). Knowledge sharing and firm innovation capability: an empirical study. International Journal of Manpower, 28(3/4), 315-332. https://doi.org/10.1108/01437720710755272.

Lin, R.-J., Chen, R.-H., \& Chiu, K. K.-S. (2010). Customer relationship management and innovation capability: an empirical study. Industrial Management \& Data Systems, 110 (1), 111-133. https://doi. org/10.1108/02635571011008434.

Liu, X., Huang, Q., Dou, J., \& Zhao, X. (2015). The impact of informal social interaction on innovation capability in the context of buyer-supplier dyads. Journal of Business Research, 78, 314-322. https://doi.org/10.1016/j. jbusres.2016.12.027.

Maatoofi Ali Reza and Tajeddini Kayhan (2011), Effect of market orientation and entrepreneurial orientation on innovation, Journal of Management Research, Vol. 11, No. 1, April 2011, pp. 20-30. https://doi. org/10.1016/j.jbusres.2016.12.027.

Matsuno, Ken, Mentzer, John T. and Özsomer, Ayegul (2002), The effects of entrepreneurial proclivity and market orientation on business performance, Journal of Marketing, 66(3): 18-32. https://doi.org/10.1509/ jmkg.66.3.18.18507.

Miller, D. (1983), The Correlates of Entrepreneurship in three types of firms, Management Science, 29 (7): 770-791. https://doi.org/10.1287/mnsc.29.7.770.

Nahapiet, J. and Ghoshal, S. (1998), "Social capital, intellectual capital and the organizational advantage", Academy of Management Review, Vol. 23 No. 2, pp. 242-66. https://doi.org/10.5465/amr.1998.533225.

O'Cass, A., \& Weerawardena, J. (2009). Examining the role of international entrepreneurship, innovation and international market performance in SME internationalisation. European Journal of Marketing, 43(11/12), 1325-1348. https://doi.org/10.1108/03090560910989911.

Panayides, Photis. (2006). Enhancing Innovation Capability through Relationship Management and Implications for Performance." European Journal of Innovation Management, vol. 9, no. 4, pp. 466-83, doi:10.1108/14601060610707876.

Pauwels, K., Silva-Risso, J., Srinivasan, S., \& Hanssens, D.M.(2004). New products, sales promotions, and 
firm value: The case of the automobile industry. Journal of Marketing,68(4), $142 \mathrm{https} / /$ doi.org/10.1509/ jmkg.68.4.142.42724-156.

Putnam, R.D. (2000), Bowling Alone: The Collapse and Revival of American Community, Simon \& Schuster, New York, NY. https://doi.org/10.1007/978-3-658-13213-2_95.

Rahomee, A., \& Ahmed, A. (2017). The mediating role of absorptive capacity on the relationship between entrepreneurial orientation and technological innovation capabilities. International Journal of Entrepreneurial Behavior \& Research, Vol. 24 No. 4, 2017 pp. 818-84. https://doi.org/10.1108/ijebr-07-2017-0233.

Rauch, A., Wiklund, J., Lumpkin, G.T. and Frese, M. (2009), Entrepreneurial orientation and business performance: an assessment of past research and suggestions for the future, Entrepreneurship Theory and Practice, Vol. 33 No. 3, pp. 761-787. https://doi.org/10.1111/j.1540-6520.2009.00308.x.

Sáenz, J., \& Bouvier, A. P. (2011). Knowledge Sharing, Innovation Networks, and Innovation Capability : The Case of Uruguayan Software Firms, 564-573. https://doi.org/10.1108/jkm-04-2013-0150.

Sanchez-famoso, V., Maseda, A., \& Iturralde, T. (2014). The role of internal social capital in organisational innovation. An empirical study of family firms. European Management Journal, 32(6), 950-962. https://doi. org/10.1016/j.emj.2014.04.006.

Shane, S. and Venkataraman, S. (2000), "The promise of entrepreneurship as a field of research", Academy of Management Review, Vol. 25, pp. 217-226. https://doi.org/10.5465/amr.2000.2791611.

Sivadas, E., \& Dwyer, F. R, (2000). An Examination of organizational factors influencing new product success in internal and alliance based processes. Journal of Marketing, 64(1), 31-49. https://doi.org/10.1509/ jmkg.64.1.31.17985.

Sulistyo, H., \& Siyamtinah. (2016). Innovation capability of SMEs through entrepreneurship, marketing capability, relational capital and empowerment. Asia Pacific Management Review, 21(4), 196-203. https://doi. org/10.1016/j.apmrv.2016.02.002.

Thornhill, S. (2006), Knowledge, innovation and firm performance in high- and low-technology regimes. Journal of Business Venturing, 21(5), 687-703. https://doi.org/10.1016/j.jbusvent.2005.06.001.

Tsai, W. and Ghoshal, S. (1998), "Social capital and value creation: the role of intrafirm networks", Academy of Management Journal, Vol. 4, pp. 464-77. https://doi.org/10.2307/257085.

Weerawardena, J. (2003), Exploring the role of market learning capability in competitive strategy, European Journal of Marketing, Vol. 37, pp. 407-30. https://doi.org/10.1108/03090560310459023.

Wiklund, J. and Shepherd, D. (2003), Knowledge-based resources, entrepreneurial orientation, and the performance of small and medium-sized businesses, Strategic Management Journal, Vol. 24 No. 13, pp. 1307-1314. https:// doi.org/10.1002/smj.360.

Wingwon, B. (2012). Effects of entrepreneurship, organization capability, strategic decision making and innovation toward the competitive advantage of SMEs enterprises. Journal of Management and Sustainability, 2(1), 137-150. https://doi.org/10.5539/jms.v2n1p137.

Workman, John P. (1993), Marketing's Limited Role in New Product Development in One Computer Systems Firm, Journal of Marketing Research, 30: 405-421. https://doi.org/10.1177/002224379303000402.

Wu, X., \& Sivalogathasan, V. (2013). Intellectual capital for innovation capability: a conceptual model for innovation. International Journal of Trade, Economics and Finance, 4(3), 139-144. https://doi.org/10.7763/ IJTEF.2013.V4.274.

Yi-Ching, T. (2006). Effect of Social Capital and Absorptive Capability on Innovation in Internet Marketing. International Journal of Management, 23(1), 157-166. Retrieved fromhttp://search.ebscohost.com/login.aspx?direct=true $\& \mathrm{db}=\mathrm{bth} \& \mathrm{AN}=20302803 \&$ site $=$ ehost-live .

Yu, X., \& Si, S. (2012). Innovation, internationalization and entrepreneurship: A new venture research perspective. Innovation: Management, Policy and Practice, 14(4), 524-539. https://doi.org/10.5172/impp.2012.14.4.524.

Zhou, L., Wu, W., \& Luo, X. (2007). Internationalization and the performance of global SMEs: the mediating role of social networks. Journal of International Business Studies, 38(4), 673-690. https://doi.org/10.1057/ palgrave.jibs.8400282. 